\title{
MIGRATION STATECRAFT MANAGING MIGRATION FLOWS AT A BILATERAL LEVEL
}

CAMILLA PAGANI MGIMO University, Moscow, 119454, Russian Federation

\begin{abstract}
This article assesses the theoretical contours and effectiveness of migration governance and diplomacy as an instrument of statecraft in interstate relations. The first part provides an overview of the stakes and challenges of migration within the fields of international relations and political theory. In particular, the category of migration defies the theoretical model of the nation-state, on which traditional IR and political theory are grounded. The second part highlights how the state, through the securitization of migration, uses migration as a tool to reaffirm its defining features: reinforcing its borders, legitimating state sovereignty, and building societal security. The third section demonstrates the usefulness of the category of statecraft within the context of migration governance at a bilateral level owing to the absence of a global normative framework. This relationship can serve different purposes, depending on the context: to harm, to deter, to bargain, to escalate. The last section presents contemporary case studies of the application of migration statecraft by the United States and Russia, as well as by member states along external border of the European Union and within the Schengen space. The elements of "migration statecraft" evidenced by these episodes focus on several objectives: trade blackmail, cooperation in an asymmetrical relation, political threat, and diplomatic escalation for electoral purposes. The variety of these cases illustrates the specificity of statecraft in comparison with foreign policy analysis. While the latter refers to a general and long-term strategy, the former is context-dependent and specific to achievement of a precise desired outcome.
\end{abstract}

\section{Keywords:}

Statecraft; Nation-state; Securitization; Migration; Russia; United States; European Union.

This article applies migration diplomacy theory [Adamson, Tsourapas 2018] to the study of evolution of contemporary statecraft. The definition of statecraft as "patterns of behaviour of states as they pursue their goals in external affairs" [Jordan et al. 2021a; 2021b] proves to be relevant within the context of migration governance at a bilateral level. Contemporary mass migration is a global phenomenon, which includes the movement of people from one state to other states due to various reasons: war, economy, labour, demography, climate change, family linkages, and many others.

This article is a result of a collaborative research project on the modern trends in the evolution of statecraft by the MGIMO School of Government and International Affairs and the Sam Nunn School of International Affairs at the Georgia Institute of Technology. A Russian version of this article is published in the second part of this special issue of International Trends. The Russian and English versions are not identical. The key term statecraft cannot be translated directly into Russian, that is why the Russian articles in this special issue use a variety of longer definitions of statecraft depending on the context. For a discussion of English and Russian definitions see the introductory article in this volume.

Manuscript received: 30.09.2020

Manuscript accepted: 17.05.2021

Corresponding author:

Email: pagani.camilla@gmail.com 
This article assesses the theoretical usefulness of "statecraft" as a category in the analysis of international migration governance. The first section provides an overview of theoretical perspectives on the stakes and challenges of migration. In particular, the category of migration defies the theoretical model of the nation-state, in which traditional IR and political theory are grounded. The second section demonstrates how states, through the securitization of migration, use migration governance as a proxy tool for the purposes of reinforcing state borders, legitimating measures to increase state sovereignty, and building societal security. The third section of the article demonstrates the usefulness of the category of statecraft for analyzing migration governance at the bilateral level. Due to the lack of a global normative framework concerning migration, the most common form of migration governance occurs at the bilateral level. This relationship can serve different purposes: to harm, to deter, to bargain, or to escalate, depending on the context. As an illustration, the last section discusses the contemporary cases of the United States, Russia, the external border of the European Union, and the borders between the Schengen zone states. I show that the tactics of "migration statecraft" may have various objectives: improving the terms of bilateral trade, forcing cooperation in an asymmetrical relationship, issuing political threats, and ginning up diplomatic escalation for electoral purposes. The variety of these case studies illustrates the specificity of statecraft in comparison with foreign policy analysis. While the latter refers to a general and long-term strategy, the former is contextdependent and specific to the achievement of a specific desired outcome.

\section{1}

In order to tackle the complexity and the multi-dimensional features of migration, it is necessary to follow an interdisciplinary approach combining political theory with international relations. Since migration ques- tions the very category of the state and the traditional state-centric perspective, it poses an explicit challenge for political and theoretical categories in both traditional IR and political theory literatures. Therefore, as a starting point, this article adopts a critical approach, looking at the multidimensional character of the migration process.

Migration refers to mobility and the flux of people, goods, services, and ideas. According to the UN, there were 272 million migrants in 2019 (3\% of the global population), 65.5 million forcibly displaced immigrants, 22.5 million refugees, and more than 10 million stateless people in the world. With this wide phenomenon of mass mobility worldwide and within the context of globalisation, we live in what has been defined as "the age of migration" [de Haas et al. 2019], or "the migration state" [Hollifield 2004]. The United Nations describes "migrant" as "an umbrella term, not defined under international law, reflecting the common lay understanding of a person who moves away from his or her place of usual residence, whether within a country or across an international border, temporarily or permanently, and for a variety of reasons"1. In addition, there are broader categories of those who temporarily cross borders, which can overlap: tourists, commuters, and expatriates.

A large amount of literature in IR highlights how migration, through the process of crossing borders, challenges most of its theoretical premises. In particular, the phenomenon of migration puts into question: a) the distinction between domestic and international realms, namely the "Great Divide" in international relations [Clark 1998]; b) the traditional statecentric approach, which is replaced by a world politics paradigm based on interdependence and transnationalism [Nye, Keohane 1971]; c) the idea of fixed borders, which causes "the end of territories" [Badie 1995]; d) the spatial idea of territory, namely the "territorial trap" [Doty 1996]; e) state security, with the introduction of the category of societal security [Waever et al. 1993]. One major theoretical

\footnotetext{
${ }^{1}$ International Organization for Migration (IOM). (2019). viewed 27th April 2021. URL: https:// publications.iom.int/system/files/pdf/iml_34_glossary.pdf (accessed: 11.06.2021).
} 
challenge to the study of IR is that the source of power and authority lies in the inviolability of the nation-state. Migration, due to its transnational nature, challenges the sovereignty and authority of the nation-state, to the extent that it threatens the principle of territorial integrity [Hollifield 2004].

From a constructivist and critical perspective, Roxanne Doty [1996] argues that, by blurring the divide between domestic and international domains, global migration breaks the "conventional spatial imagery" of territory and the interconnection between territory, national identity, and political community. In other words, migration discloses a "territorial trap", which was based on three arguments: a) states as fixed units of sovereign space; b) the dichotomy between domestic and international arenas; c) states as spatial containers of societies. In addition, illegal immigration undermines the authority of sovereign states. Doty looks at borders and boundaries not as a natural given, but as subjects of negotiation, disputes, and national interests.

Likewise, in political theory literature, migration challenges a number of aspects of the nation-state model, including the category of membership in a polity [Arendt 1976; Walzer 1983], the ideas of political representation [Benhabib 2005], and national identity [von Busekist 2004]. These criticisms usually follow two paths: either the multicultural theory [Kymlicka 2007] or the post-nationalist and globalization theories [Appadurai 1996]. The nation-state model is based on the premise that the state as "the political structure where sovereign power is exercised within a specific territory over a population" is defined through three interconnected elements: territory, population, and sovereignty [Bobbio 1989: 90]. This model relates to Westphalian sovereignty, which is grounded in the idea of territorial integrity and borders. By contrast, "nation", following a constructivist approach, is a more recent ideology that binds people together in a shared network of values, interests, cultures, and languages through state-led policies in education, media and culture [Anderson 2006; Gellner 1983]. According to Agnès Czajka [2014], from a Foucauldian per- spective, state and nation were conceived as opposites before the French Revolution. The state epitomized the sovereign, whereas the nation the people. After the Revolution and especially during the $19^{\text {th }}$ and $20^{\text {th }}$ century, the nation-state was conceived as a category whose main purpose was the protection of its citizens, understood as its nationals [Foucault 2003]. Similarly, Hannah Arendt defines the nation-state as a "tragic" result of the combination of state and nationality. Her theory of "the right to have rights" demonstrates how the state changed from being an instrument of the law to becoming an instrument of the nation, excluding de facto those who were not members of the national community [Arendt 1976: 230].

The issue of membership and the classification of categories of people, be they citizens or stateless, is key to understanding the contemporary theoretical challenges brought to political theory by migration. Accordingly, American liberal philosopher Michael Walzer underlines the importance of membership in a political community and stresses the divide between nationals and foreigners (namely metics), citizens, and denizens [1983: 87]. Access to citizenship rights and the attainment of political membership rights by nonmembers are among the most important contemporary political issues. Migrants do not belong to a single nation-state; rather they move from one state to another or many others, mixing and combining identities (in some cases even having dual citizenships), paying taxes in different countries, voting in a country other than their nationality, and building links across countries, languages, cultures, and religions. Political philosopher Seyla Benhabib argues that the very scale of global migration causes a crisis of territoriality. According to her theory, the normative model in which a unitary concept of citizenship corresponds to a defined territory, a national identity, and an administrative bureaucracy no longer exists [2005]. The EU provides an outstanding case of this form of "disaggregation of citizenship", distancing the categories of territory, citizenship, and national identity. The privileges of political membership are 
indeed allocated to all citizens of member countries of the Union who may reside in territories other than those of their nationality. The divide has therefore shifted to insiders/ outsiders of the EU, as the case of Brexit has perfectly demonstrated.

Because migration challenges the sovereignty of the nation-state, the state, through various policies of securitization, uses migration as a way to reaffirm the importance of borders and to define territories and national identities. Within the framework of the politics of fear, the securitization of migration has been developed as a new political category within the context of homeland security and the "war on terror". Since 9/11, migration has become above all an international security concern. According to the critical school of security studies, securitization of migration is carried out through various policies: a) the framing of legal/illegal, regular/irregular migrants, asylum seekers/economic migrants as potential threats [Huysman 2006]; b) the use of technologies of control like DNA fingerprints, electronic tagging, biometric ID cards, passports, and facial recognition systems, smart CCTV systems, screening, and risk-profiling; c) the overlapping of military and police functions [Bigo 2014]; d) the connection between security, borders, and immigration [Bigo 2011]; e) suspicions of illegality and the criminalization of migration, or "crimmigration" [Resnik 2017; Benhabib, 2020].

Securitization of migration is a state-led policy of control, border design, identity politics, and foreign relations. From this perspective, it should be considered as a policy that allows the state to reaffirm its power and to "reterritorialize the deterritorialized flows inherent in globalization" by "reproducing boundaries (spatial, social, cultural, economic, and political) as natural" [Doty 1996: 175]. By placing nationals and foreigners, and legal and illegal migrants, in opposition, and by dividing citizens into those who will be allowed to cross state borders and others that will not, whilst tracking all their move- ments, governments try to reaffirm the sovereignty of the state [Huysman 2006]. Border controls and migration governance become state priorities to the extent that they are meant to protect its defining features: territorial integrity, sovereignty, and the identity of a population or "societal security" [Buzan, Waever 1993].

Classification of migrants or decisions over migrant quotas can become powerful "weapons" in interstate relations [Greenhill 2010]. Instead of being a challenge, migration becomes a strategic tool for states to reaffirm their sovereignty through policies of securitization. The management of migration flows is therefore at the core of state's interests, in particular in their bilateral relations.

Nonetheless, there is a theoretical dilemma in traditional IR: prioritizing the nation-state makes it difficult to fully grasp the complexity and multi-dimensionality of the migration process in its relational aspect. By contrast, statecraft proves to be a useful analytical tool in the field of interstate migration governance. More dynamic than foreign policy analysis, statecraft studies are better suited for migration policy comparisons [Jordan et al. 2021a; 2021b].

Although migration is a global and permanent phenomenon, multilateral migration governance is weak, while a unified body of international migration law is absent. Therefore, regulation of migration is a key aspect of state sovereignty and interstate relations [Hampshire 2013]. According to Hampshire, there are several modes of migration governance: a) formal multilateralism, b) informal multilateralism; c) the EU as a supranational regional governance structure, and, most importantly, d) bilateral relations.

Formal multilateralism is typical of the international refugee management system, which is based on the 1951 Convention and its 1967 Protocol. It is overseen by the UN High Commissioner for Refugees and is grounded in the non-refoulement principle: "the right of refugees not to be returned to a country where they risk persecution". Worldwide, there are 
22.5 million refugees, with $80 \%$ of them residing in developing countries [UN 2019]. Informal multilateralism, by contrast, is not binding, and applies to the context of the North-South dialogue on migration and developments such as the annual intergovernmental meeting of the Global Forum on Migration and Development. Furthermore, the European Union is based on dualism between free movement of goods, services, capital, and people within the Schengen area - a supranational regional governance structure on the one hand, and strong external border security on the other hand [Huysmans 2000]. Bilateral relations at the regional level are by far the most common form of interstate migration governance. It is precisely within this framework that the concept of statecraft becomes primordial. How is migration managed at the bilateral level? What are the outcomes of particular choices of migration governance for the states involved?

In international relations, statecraft can be considered as a toolbox with different instruments to be chosen in terms of desired outcomes and effectiveness depending on each a particular context ${ }^{2}$. There are three main categories of tools: military, economic, and soft power. Soft power includes diplomacy, information, religion, and language policies [Crowley-Vigneau, Le Saux 2021], as well as diasporas. The combination of different statecraft tools enables achieving specific and concrete objectives depending on the status of one's counterpart. In the post-Cold War context, where "low politics" competes with "high politics", social, cultural, and soft power is used as an instrument besides traditional military, economic and political power. Within this framework, the "tool" of the securitization of migration plays a key role in interstate relations. The current global context has been described as a gray zone between peace and war, where different asymmetries coexist: asymmetries of power, of stakes, of values [Jordan et al. 2021a; 2021b]. Other rising asymmetries in current global trends are the asymmetry of climate and the asymmetry of demography, with a growing pressure from Africa on Europe, from Latin America and the Caribbean on North America, and from Central and South Asia on Western Asia [UN 2019].

Decisions to open or close a border, allowing or preventing the movement of millions of people, can become powerful tools of negotiation, bargaining, threat, or escalation. Statecraft, understood as an "attempt to exert influence over another state short of the resort to brute military force" [Jordan et al. 2021a; 2021b], is a suitable interpretive lens of analysis in the field of migration. More precisely, it should be applied to the field of "migration diplomacy", namely a "state's use of diplomatic tools, and procedures to manage cross-border population mobility" as stated by Adamson and Tsouparas [2018: 3]. According to them, migration diplomacy focuses "on how states employ cross-border population mobility management in their international relations, or how they use diplomatic means to obtain goals relating to migration" [2018: 4].

Likewise, statecraft should be considered as a tool by which a state achieves its foreign policy ends short of using force. According to Jordan, Stulberg and Troitskiy [2021a; 2021b], statecraft has a multi-dimensional character aimed at influencing others' choices. Looking at migration from the perspective of statecraft understood as patterns of behaviour undertaken to achieve measurable outcomes, one can distinguish various tactics of "migration statecraft". Interstate bargaining over migration proves to be an effective instrument in order to achieve measurable outcomes, especially within a context of an asymmetrical power relationship. The UK-EU Brexit negotiations provide a telling case. The 2016 referendum was meant to end freedom of movement and to make EU citizens subjects to the same immigration rules as citizens from the rest of the world [Walsh 2020]. The threat of border closures for Europeans in the UK and conversely for British citizens in the EU, involving respectively nearly 3 million and 1 million citizens, as well as defying the right

2 Zagorskyi. A (2020). Lecture MGIMO-Gatech. 
of free movement of people were key bargaining instruments during Brexit negotiations. The UK Immigration Act, which was passed by the House of Commons on 18 May 2020, introduced a points-based system, which likens Europeans to non-Europeans, making Europeans potential immigrants.

Migration statecraft varies depending on the state's status. According to Adamson and Tsouparas, the mode of "strategic use of migration flows" depends on whether a receiving, a sending, or a transit state is involved, although in some cases these statuses may overlap. First, a sending state could adopt emigration diplomacy as a means of influencing target countries, as Egypt did during the 1950s and 1960s in the Arab world [2018: 6]. Second, a receiving state might change its immigration norms depending on specific objectives of its foreign policy. Likewise, Robbie Totten's historical research on the use of immigration in US foreign policy strategy demonstrates how migration laws have been modified in order to achieve pre-meditated outcomes. His study specifically shows how migration as an instrument of statecraft makes it possible to reach three foreign policy objectives: to please allies, to harm adversaries, and to bargain. For instance, Totten considers the case of US immigration diplomacy vis-à-vis people fleeing the Soviet Union as a way of harming adversaries [2017: 354]. Third, a transit state can act differently depending on the context and on its relations with the other involved countries. Adamson and Tsouparas argue that in general transit states possess "zero-sum mentality", as evidenced by Libya during Gaddafi's "coercive migration diplomacy" or Turkey during Erdogan's presidency.

Finally, as an instrument of influence, migration statecraft refers to the achievement of concrete economic, political, or other goals in a short-term perspective - in a defensive or offensive manner - while maintaining or changing the status quo.

\section{4}

"Migration statecraft" should be considered as a cross-domain tool that a state uses in its bilateral relations in order to achieve a specific goal within a context of asymmetries of power and/or stakes, short of resorting to the military option. The following case studies illustrate how migration was securitized as an instrument of statecraft by tightening border controls. Migration statecraft cannot serve longterm foreign policy goals; it is available only in certain contexts, while the actors involved can usually adapt their policies to neutralize its impact. Migration statecraft can be employed in a zero-sum context, such as the Gaddafi-era agreement between Libya and the EU [Greenhill 2010] or in a positive-sum context, such as cooperation between Russia and some of its neighbors [Ivakhniuk 2017].

a) Bordering as trade blackmail: US/Mexico

In the case of the United States and Mexico, the asymmetries of power are very significant. With a 50-million immigrant population, the US receives the highest number of immigrants of all countries [UN 2019]. Liberal philosopher Michael Walzer defined American identity not in terms of a particular ethnic group, but as "a politics that is qualified by so many religions and nationalities as to be free from any one of them" [1990: 598]. By contrast, Mexico is at the same time a sending and a transit state. Migrants from Mexico represent the second largest diaspora in the world with 11.8 million people [UN 2019]. Remittances from the United States account for 3\% of Mexico's GDP, the thirdlargest source of foreign revenue after oil and tourism. Nonetheless, recent studies show that emigration from Mexico has dropped, while transit migration through Mexico from Honduras, El Salvador, and Guatemala on the way towards the US has increased [Meierotto 2020: 158].

The aggressive bordering strategy practiced by United States - especially during the years of the Trump administration - had twin domestic and foreign policy objectives. Domestically, Trump built its political campaign on the promise to build a wall on the US border with Mexico. The foreign policy objective was to put pressure on Mexico in the context of a trade negotiation. Trump's instrument of choice for immigration policy was travel ban [White House 2017]. Immigration rules were 
further tightened amid rising unemployment during the COVID-19 pandemic ${ }^{3}$.

Changes to the crossing regime on the US-Mexican border directly affects 12 million people living in the area. Organized crime, including drug smuggling rings, operate across this border, with 224 illegal tunnels discovered between 1990 and 2016 [Felbab-Brown 2017]. The US-Mexican border provides one of the clearest examples of the securitization of migration [Meierotto 2020]. US legal scholar Judith Resnik employs the concept of "crimmigration", namely the criminalization of migration, to explain the merging of criminal law and immigration system in the United States since the 2010s. As a result, prosecution of illegal migration accounted for more than a half of the annual caseload in US federal courts between 2008 and 2015 [Resnik 2017]. The Trump administration increased this phenomenon by extending the criteria for "expedited removal", viz. "a process by which low-level immigration officers can quickly deport individuals who are undocumented or have committed fraud or misrepresentation"4.

Trump's policy of hardening the border with Mexico went hand-in-hand with threats to impose tariffs on imported Mexican goods. In May 2019, President Trump directly linked the threat of tariffs with the demand that Mexico stop US-bound migrants. In June 2019, the United States and Mexico signed a migration agreement to prevent the imposition of tariffs. Accordingly, Mexico agreed to employ the National Guard on its borders, dismantle human trafficking networks, and adopt migrant protection protocols. The protocols provide for Mexico to host asylum seekers and give them access to jobs, healthcare, and education while they wait for the adjudication of their asylum claims to the US'.

In a nutshell, the relationship between the United States and Mexico epitomizes the liberal paradox described by Hollifield [2004]: the need for commercial openness and trade coexists with the pressure for closing borders for political and security purposes. In 2019 Mexico became United States' primary trading partner (\$614.5 billion), replacing China [Roberts 2020]. In July 2020 a United States-CanadaMexico Agreement (USMCA) came into force as a replacement for the North American Free Trade Agreement (NAFTA). In this relationship, securitization of migration proved to be a key tool of statecraft. An aggressive politics of bordering coupled with threats concerning the terms of trade with Mexico allowed the United States to achieve desired domestic and foreign policy objectives. In its turn, as a transit state, Mexico enacted a similar approach to securitizing migration within its own territory, aiming to safeguard its exports to the US. Considering the prominent role of migration in US-Mexico relations, migration statecraft proved to be a more successful cross-domain tool to advance trade goals, as compared to military or diplomatic options.

b) Negotiating regional integration: Russia and the Commonwealth of Independent States

According to the UN, Russia is the fourth largest country in terms of immigration, with a migrant population originating from Central Asia (Kyrgyzstan, Tajikistan, Uzbekistan) and the South Caucasus (Armenia, Azerbaijan) ${ }^{6}$. It has adopted a visa-free policy limited to 90 days for migrant workers coming from the former Soviet countries of the Commonwealth of Independent States. Nonetheless, many of

\footnotetext{
${ }^{3}$ Proclamation-Suspension of Entry as Immigrants and Nonimmigrants of Certain Additional Persons Who Pose a Risk of Transmitting 2019 Novel Coronavirus. U.S. White House. 2020. URL: https://www. whitehouse.gov/presidential-actions/proclamation-suspension-entry-immigrants-nonimmigrants-certainadditional-persons-pose-risk-transmitting-2019-novel-coronavirus/ (accessed: 27.04.2021).

${ }^{4}$ American Immigration Council 2019, A Primer on Expedited Removal. URL: www. americanimmigrationcouncil.org (accessed: 27.04.2021).

5 Joint Declaration and Supplementary Agreement Between the United States of America and Mexico. U.S. Department of State. 07.06.2019. URL: https://www.state.gov/u-s-mexico-joint-declaration/ (accessed: 27.04.2021).

${ }^{6}$ Trends in International Migration, Population Facts. No. 4. New York: United Nations Department of Economic and Social Affairs, 2019. URL: https://www.un.org/en/development/desa/population/migration/ publications/index.as (accessed: 27.04.2021).
} 
these workers are not counted in official statistics, leading to a large unaccounted immigrant population from Central Asia working in the informal economy [Schenk 2018].

In order to understand migration into Russia, one should look at the system of migration flows across Eurasia as a system in which the knowledge of the Russian language provides migration opportunities, while intraregional migration on a considerable scale corresponds to the interests of many regional players [Ivakhnyuk 2017]. Since the collapse of the USSR, migration within the post-Soviet region has been intense. Between 1989 and 2007, 3.6 million ethnic Russians relocated to Russia. Currently Russia has an official foreign-born population of 11 million people, but the real numbers are higher given the large number of temporary workers and illegal migrants. According to political scientist Caress Schenk, there may be 16 to 18 million immigrants in Russia from other CIS countries [2018]. Since 2002, within the context of the second Chechen war, migration has been a security concern for Russia. Domestically, xenophobia and fear of immigration were counterbalanced by need for labour resources. After testing in the Russian language was introduced in 2015 as a requirement to obtain work permits, many migrant workers have taken the path of illegal employment [Ivakhniuk 2017].

The cultural legacy of the Soviet Union and the need for political stability in the region have influenced Russia's migration statecraft. Most migrants arrive in Russia from CIS countries that are Russia's main partners in regional integration [Chudinovskikh, Denisenko 2014]. Russia's key interest in the region is to boost economic and political integration. In an official statement in November 2016, President Putin stated that developing "bilateral and multilateral cooperation with CIS member states and further strengthening integration structures operating in the CIS space" constituted Russia's foreign policy priorities [Ivakhniuk 2017]. Because Russia and other countries have a common interest in regional economic advancement and integration, Moscow regards migration as a positive-sum game. There are considerable asymmetries of power and stakes among post-Soviet countries. Russia has bilateral inter-governmental agreements on labor migration with Tajikistan (2004) and Uzbekistan (2007).

Analyses of international migration in the post-Soviet region should take into account the existence of the Eurasian Economic Union. According to Ryazantsev et al. [2017: 40] "labor migration has become a form of mutual economic and political integration of former Soviet republics, facilitating the creation of the Eurasian Economic Union (EAEU)". Along similar lines, Ivakhniuk argues that "the consistently constructive stance that the CIS countries take on migration cooperation will largely determine the future of integration in the post-Soviet space" [2017]. EAEU members enjoy free movement and employment for their citizens across the Union. Such opportunity may be "an important incentive for other states to join this regional integration structure" [Ivakhniuk 2017]. For instance, Uzbekistan announced its interest in becoming a Eurasian Union observer state. In an official address to the Uzbek parliament in January 2020, President Shavkat Mirziyoev stated: "With a view of creating favourable conditions for our citizens, who are working in Russia and Kazakhstan, at the moment we are scrutinizing the issue of putting in place Uzbekistan's interaction with the Eurasian Economic Union"7.

Russia's migration statecraft, therefore, should be considered in connection with Moscow's interest in regional integration. In asymmetrical relations with its neighbors, Russia needs to reach two main goals: to meet the need for immigrant labor and to foster economic and diplomatic relations in the strategic post-Soviet region. Since regional stability is one of Russia's priorities, its ability to regulate regional migration is becoming a key objective for balancing these objectives for Moscow.

\footnotetext{
${ }^{7}$ Address by the President of the Republic of Uzbekistan Shavkat Mirziyoyev to the Oliy Majis. UN Permanent Mission of the Republic of Uzbekistan. 2020. URL: https://www.un.int/uzbekistan/news/ address-president-republic-uzbekistan-shavkat-mirziyoyev-oliy-majlis-0 (accessed: 27.04.2021).
} 
Securitization of migration can become an important source of leverage in a trade negotiation, while the ability to influence international migration governance allows for controlling and safeguarding social stability and security in a very diverse region. Tajikistan, for example, is highly dependent on migrant remittances from migrants working in Russia: they provided $28 \%$ of its GDP in $2018^{8}$. These remittances are a key factor of social cohesion as well as of national and regional security.

\section{c) Political threat: Turkey/EU}

The political threat posed by Turkey as a transit state to the European Union and the "world's main destination regions for immigrants" (Hampshire, 2013, p. 98) represents a noteworthy case of migration statecraft (although the EU is not a state, but a supranational region). According to Hampshire, EU governance provides an interesting exception as it is based on supranational policymaking processes and not on intergovernmental negotiations in which individual states could wield a veto.

Under the pressure of the migration crisis during the civil war in Syria, where one million refugees and other migrants arrived in the $\mathrm{EU}$ in 2015, Turkey and the European Union reached an agreement in March 2016 ${ }^{9}$. According to this agreement, Ankara had to control the outflow of migrants from Turkey and accept the Syrian refugees returned from the Greek islands around Turkey. In exchange, Turkey received 6 billion euros in EU aid for migrants and refugees. The agreement also provided that: a) for each Syrian individual resettled from Greece to Turkey, another would be resettled from Turkey to the EU; and b) the EU was meant to work towards lifting visa requirements for Turkish citizens by the end of June 2016. As a result, the number of migrants arriving to Greece precipitously dropped [Terry 2021].

Nevertheless, due to the worsening of political relations between Turkey and the EU, the European Parliament voted on November 2016 to suspend EU membership meetings with Turkey. Consequently, Turkish President Recep Tayyip Erdogan threatened to cancel the deal on migration governance and to open its borders ${ }^{10}$. Turkey, as a transit state, was already hosting 3.7 million Syrian refugees, as well as migrants from other countries such as Afghanistan. Turkey's strategic geographical position in the Eastern Mediterranean and the ability to control the flow of refugees and migrants into the European Union constituted a key bargaining tool in Turkish migration statecraft [Adamson, Tsouparas 2018; Içduygu, Üstübici 2014; Greenhill 2016].

As the humanitarian situation in Syria deteriorated, with the number of refugees approaching one million, this threat became even more potent in 2020, when President Erdogan stated that Turkey was no longer willing to prevent migrants from entering the EU and allowed migrants to pass through its territory and reach the Greek border. Unlike during the 2016 deal, in 2020 Turkey-EU relations had significantly worsened. In this context, migration was perceived as a bargaining instrument within the Syrian conflict framework ${ }^{11}$ and in the competition for energy in the Eastern Mediterranean [Talbot 2020]. Turkey's energy interests, driven by its Blue Homeland doctrine [Çandar 2020] and the discovery of natural resources around the divided island of Cyprus, led state-owned company Turkish Petroleum (TPAO) to conduct drilling activi-

\footnotetext{
8 World Bank. 2019. URL: https://data.worldbank.org/indicator/BX.TRF.PWKR.DT.GD.ZS?locations =TJ (accessed: 27.04.2021).

${ }^{9}$ EU-Turkey statement. European Council (EC). 18 March 2016. URL: www.consilium.europa.eu/en/ press/press-releases/2016/03/18/eu-turkey-statement (accessed: 27.04.2021).

10 Mortimer C. (2016). President Erdogan: I Will Open Gates for Migrants to Enter Europe If EU Blocks Membership Talks. Independent. URL: https://www.independent.co.uk/news/world/europe/ presidenterdogan-turkey-eu-membership-migrants-refugees-europe-warning-a7438316.html (accessed: 27.04.2021).

11 Stevis-Gridneff M., Kingsley P. (2020). Turkey, Pressing E.U. for Help in Syria, Threatens to Open Borders to Refugees. The New York Times. URL: https://www.nytimes.com/2020/02/28/world/europe/ turkey-refugees-Geece-erdogan.html (accessed: 27.04.2021).
} 
ties in waters internationally recognized as part of the Exclusive Economic Zone (EEZ) of the Republic of Cyprus, an EU member state [Skinner 2020]. This provoked an escalation between Turkey, Cyprus, and Greece, and consequently with the EU.

As these tensions escalated, migration statecraft was used as an instrument of political leverage. Given European leaders' fear of another migration crisis, Erdogan was in a "particularly favorable position regarding any potential conflict with the EU" [Skinner 2020].

The difference between the Turkish and Mexican cases boils down to two main aspects. Firstly, unlike Turkey, Mexico is also an emigration state, which makes it more vulnerable to additional US restrictions on migration. Secondly, Mexico came under direct threat of economic sanctions by the US that, in turn, made it more pliable; in its turn, Turkey had a much stronger hand in negotiations with the EU on migration because of Ankara's key geostrategic position in the Mediterranean, as well as EU leaders' determination to avoid another potential migration crisis.

\section{d) Escalation: Italy and France in 2019}

Although Italy and France are historical partners and founding states of the European Union belonging to the Schengen space, they recently experienced a few episodes of diplomatic and political escalation around migration governance at the border between them. In February 2019, the French ambassador in Italy was recalled from Rome after months of tensions. French foreign ministry officials described it as having no precedent since 1940. Several diverging interests weighed in on the border regime negotiations, including the political fragmentation in Libya, political interference by representatives of the Italian government into the yellow vests movement, and a migration crisis on the French-Italian border [Pagani 2019].

From 2013 onwards, Italy felt abandoned by its EU partners on migration governance issues. Every European country has been following a nationalist policy in pursuit of electoral and self-centered interests. The French-Italian border became an object of securitization, causing transportation backlogs and negatively affecting the daily life of the local population. As a matter of fact, a few incidents happened at the border in Clavière in the Alps during October 2018. Italy set up a border patrol in response to French police intrusions into Italian territory in the course of operations to expel illegal migrants. This incident resulted in a tense dispute involving Italian and French interior ministers. The opportunistic and calculated use by the sides of border security issues can be understood in the context of the upcoming European elections.

Migration was not the only source of controversy between Italy and France, as well as among EU members in general, in the run-up to the election. Nonetheless, the management of migration and border security played a key role in affecting and influencing various decisions and interests at that specific political moment. By upping the ante, Matteo Salvini and the new EU parliamentary political group "Identity \& Democracy" tried to consolidate an alliance with Marine Le Pen's Rassemblement National and other European populist leaders by posing as strong opponents of the European liberal model. Salvini's main adversary was French President Emmanuel Macron, who represented the European liberal group, and not the Secretary of the Italian Democratic Party Nicola Zingaretti. Ginning up tensions around migration across the French-Italian border served as an instrument of statecraft for achieving the electoral result desired by the key Eurosceptic members of the Italian government. This act of escalation was the sign of the Europeanization of the political debate, rather than a rivalry between two historical partners [Pagani 2019].

$* * *$

This article provides evidence of the nexus between migration, security, and statecraft, by bridging the perspectives of international relations and political theory. The article contributes to the testing of the effectiveness of statecraft as a category of analysis. Using the case studies of the United States, Russia, and the European Union, I demonstrate the range of tactics available to the users of migration statecraft. 
Although these cases differ by scale, context, and geography, they highlight the potent applications of migration statecraft. Within the context of power asymmetries, and short of resorting to the military option, securitization of migration in bilateral relations can serve specific and concrete objectives: a) improve- ment of the terms of trade with Mexico for the United States; b) beefing up Russia-led economic and political integration projects in post-Soviet Eurasia; c) extracting political concession for Turkey from the European Union; and d) campaigning in a European election, as in the case of Italy and France.

\section{References}

Adamson F.B. (2006). Crossing Borders: International Migration and National Security. International Security. Vol. 31. No. 1. P. 165-199.

Adamson F.B., Tsourapas G. (2018). Migration Diplomacy. World Politics. International Studies Perspectives. Vol. 20. No. 2. P. 1-16. DOI: 10.1093/isp/eky015

Anderson B. (2006). Imagined communities. Reflections on the origin and spread of nationalism. London, New York: Verso. 240 p.

Appadurai A. (1996). Modernity at Large: Cultural Dimensions of Globalization. Minneapolis: University of Minnesota Press. $229 \mathrm{p}$.

Arendt H. (1976). The Origins of totalitarianism. Orlando: Harvest Book. 527 p.

Badie B. (1995). La fin des territoires. Essai sur le désordre international et l'utilité sociale du respect. Paris: Fayard. 282 p.

Benhabib S. (2005). Borders, Boundaries, and Citizenship. Political Science and Politics. Vol. 38. No. 4. P. 673-677.

Benhabib S. (2020). Decriminalizing Migration: Moral Resources, Juridical Ideas. Reset-DOC. URL: https://www.resetdoc.org/story/decriminalizing-migration-moral-resources-juridical-ideas/ laccessed: 27.04.2021).

Bigo D. (2011). Le "Nexus" Sécurité, Frontière, Immigration : Programme Et Diagramme. Cultures Et Conflits. No. 84. P. 7-12.

Bigo D. (2014). The (In)Securitization Practices of the Three Universes of EU Border Control: Military/ Navy - Border guards/police - database analysts. Security Dialogue. Vol. 45. No. 3. P. 209-225.

Bobbio N. (1989). Democracy and Dictatorship: The Nature and Limits of State Power. Oxford: Polity Press. $186 \mathrm{p}$.

Busekist von A. (2004). Uses and Misuses of the Concept of Identity. Security Dialogue. Vol. 35. No. 1. P. 35-81. DOI: 10.1177/0967010604042537

Crowley-Vigneau A., Le Saux F. (2021). Language and Statecraft. Mexhdunarondye protsessy. Vol. 19. No. 1. P. 92-106.

Çandar C. (2020). Turkey's Blue Homeland Doctrine: Signaling Perpetual Conflict in the Mediterranean and Rough Waters Ahead. The Turkey analyst. URL: https://www.turkeyanalyst.org/publications/ turkey-analyst-articles/item/648-turkey\%E2\%80\%99s-blue-homeland-doctrine-signaling-perpetualconflict-in-the-mediterranean-and-rough-waters-ahead.html (accessed: 27.04.2021).

Clark I. (1998). Beyond the Great Divide: Globalization and the Theory of International Relations. Review of International Studies. Vol. 24. No. 4. P. 479-498.

Chudinovskikh 0., Denisenko M. (2014). Population Mobility in the Commonwealth of Independent States: Whither Common Migration Policy? CARIM-East Research Report. CMR Working Papers, no 74 (132), Centre of Migration Research, University of Warsaw.

Czajka A. (2014). Migration in the Age of the Nation-state: Migrants, Refugees, and the National Order of Things. Alternatives: Global, Local, Political. Vol. 39. No. 3. P. 151-163.

Doty R. (1996). The Double-Writing of Statecraft: Exploring State Responses to Illegal Immigration. Alternatives: Global, Local, Political. Vol. 21. No. 2. P. 171-189.

Felbab-Brown V. (2021). The Wall. The real costs of a barrier between the United States and Mexico. Brookings. URL: https://www.brookings.edu/essay/the-wall-the-real-costs-of-a-barrier-between-theunited-states-and-mexico/ Caccessed: 27.04.2021].

Foucault M. (2003). Society Must Be Defended. Lectures at the Collège de France, 1975-1976. New York: Picador. 310 p.

Gellner E. (1983). Nations and nationalism. Ithaca, New York: Cornell University Press. 150 p.

Greenhill K. (2010). Weapons of Mass Migration: Forced Displacement, Coercion, and Foreign Policy. Ithaca, New York: Cornell University Press. 342 p.

Greenhill K. (2016). Open Arms Behind Barred Doors: Fear, Hypocrisy, and Policy Schizophrenia in the European Migration Crisis. European Law Journal. No. 22. P. 317-32. 
de Haas H. Castles S. \& Miller M.J. (2020). The Age of Migration. International Population Movements in the Modern World. London: Macmillan Education. 401 p.

Hampshire J. (2013). The Politics of Immigration: Contradictions of the Liberal State. Cambridge: Polity Press. 224 p.

Hollifield J. (2004). The Emerging Migration State. The International Migration Review. Vol. 38. No. 3. P. 885-912.

Huysmans J. (2000). The EU and the securitization of migration. Journal of Common Market Studies. Vol. 38. No. 5. P. 751-777.

Huysmans J. (2006). The Politics of Insecurity: Fear, Migration and Asylum in the EU. London: Routledge. $191 \mathrm{p}$.

Içduygu A., ÜStüBici A. (2014). Negotiating Mobility, Debating Borders: Migration Diplomacy in TurkeyEU Relations. In: Schwenken H., Russ-Sattar S. (eds) New Border and Citizenship Politics. London: Palgrave Macmillan. P. 44-59.

Ivakhnyuk I. (2017). Proposals For Russia's Migration Strategy Through 2035. Moscow: RIAC. URL: https://russiancouncil.ru/en/activity/publications/proposals-for-russia-s-migration-strategythrough-2035/

Jordan J., Stulberg A. \& Troitskiy M. (2021a). Statecraft in U.S.-Russia Relations: Meaning, Dilemmas, and Significance. Mezhdunarodnye protsessy. Vol 19. No. 1e. P. 4-17.

Jordan J., Stulberg A. \& Troitskiy M. (2021b). Statecraft in U.S.-Russia Relations: Meaning, Dilemmas, and Significance. Mezhdunarodnye protsessy. Vol. 19. No 1r. P. 6-25.

Kymlicka W. (2007). Multicultural Odysseys. Navigating the New International Politics of Diversity. New York: Oxford University Press. 374 p.

Meierotto L. (2020). Immigration, Environment, and Security on the U.S.-Mexico Border. London: Palgrave Macmillan. $250 \mathrm{p}$.

Nye J., Keohane R. (1971). Transnational Relations and World Politics: An Introduction, International Organization. Vol. 25. No. 3. P. 329-349.

Pagani C. (2019). Cold Wind Across the Alps: Franco-Italian Rivalry and the Europeanization of Political Competition. Reset-DOC. URL: https://www.resetdoc.org/story/cold-wind-across-alps-franco-italianrivalry-europeanization-political-competition/ (accessed: 27.04.2021).

Resnik J. (2017). Bordering By Law: The Migration Of Law, Crimes, Sovereignty, And The Mail. Nomos. Vol. 57. American Society for Political and Legal Philosophy. P. 79-201.

Roberts K. (2020). It's Official: Mexico Is No. 1 U.S. Trade Partner For First Time, Despite Overall U.S. Trade Decline. Forbes. URL: https://www.forbes.com/sites/kenroberts/2020/02/05/its-official-mexicois-no-1-us-trade-partner-for-first-time-despite-overall-us-trade-decline/ (accessed: 27.04.2021).

Ryazantsev S., Bogdanov I., Dobrokhleb V. \& Lukyanets A. (2017). Migration from central Asian countries to Russia and Kazakhstan in the context of integration processes in the Eurasian economic union format. Central Asia and the Caucasus. Vol. 18. P. 39-49.

Schenk C. (2018). Why Control Immigration? Strategic Uses of Migration Management in Russia. Toronto: University of Toronto Press. 374 p.

Skinner A. (2020). Erdogan Unlikely to Back Down in Mediterranean Despite Oil and Gas Glut. Washington Institute. URL: https://www.washingtoninstitute.org/policy-analysis/erdogan-unlikely-back-downmediterranean-despite-oil-and-gas-glut laccessed: 27.04.2021).

Talbot V. (2020). Turkey's Struggle for Influence in the Eastern Mediterranean. Italian Institute for International Political Studies. URL: https://www.ispionline.it/en/pubblicazione/turkeys-struggleinfluence-eastern-mediterranean-26977 (accessed: 27.04.2021).

Terry K. (2021). The EU-Turkey Deal, Five Years On: A Frayed and Controversial but Enduring Blueprint. Migration Policy Institute. URL: https://www.migrationpolicy.org/article/eu-turkey-deal-five-years-on (accessed: 27.04.2021).

Totten R. (2017). Statecraft and Migration: A Research Note on American Strategies to Use Immigration in Foreign Policy from the Founding Era through the Early Twenty-First Century. Diplomacy \& Statecraft. Vol. 28. No. 2. P. 344-370.

Wæver O., Buzan B., Kelstrup M., Lemaitre P. (1993). Identity, Migration and the New Security Agenda in Europe. New York: St. Martin's Press. 221 p.

Walsh P.W. (2020). The new Immigration Bill: closing the door on freedom of movement. The Migration Observatory at University of Oxford. URL: migrationobservatory.ox.ac.uk/resources/commentaries/ the-new-immigration-bill-closing-the-door-on-freedom-of-movement (accessed: 27.04.2021).

Walzer M. (1983). Spheres of Justice: A Defense of Pluralism and Equality. New York: Basic Books. $345 \mathrm{p}$.

Walzer M. (1990). What Does It Mean to Be an "American"? Social Research. Vol. 57. No. 3. P. 591-614. 


\title{
ИНСТРУМЕНТАЛИЗАЦИЯ МИГРАЦИИ \\ УПРАВЛЕНИЕ МИГРАЦИОННЫМИ \\ ПОТОКАМИ В ДВУСТОРОННЕМ ФDPMATE
}

\author{
КАМИЛЛА ПАГАНИ \\ МГИМО МИД России, Москва, Россия
}

\begin{abstract}
Резюме
В настоящей статье разрабатываются теоретические подходы к оценке успешности инструментализации миграции и миграционной дипломатии в межгосударственных отношениях. В первом разделе представлен обзор рисков и проблем миграции с точки зрения исследований международных отношений и политической теории. В частности, миграция бросает вызов модели национального государства, на которой базируются устоявшиеся исследовательские традиции. Во втором разделе демонстрируется, как государство посредством секьюритизации использует миграционные потоки в качестве инструмента для подтверждения своих определяющих характеристик: укрепления национальных границ, легитимации государственного суверенитета и поддержания общественной безопасности. В третьем разделе обосновывается полезность концепции управления внешнеполитическими ресурсами (statecraft) для анализа миграции на двустороннем уровне при отсутствии международно-правовой базы. Посредством миграционной политики возможно причинять вред другим государствам, сдерживать их, усиливать переговорные позиции, повышать ставки в ходе конфликта. В последнем разделе статьи представлены исследования, показывающие каким образом США, Россия, а также некоторые государства-члены Европейского Союза пытаются использовать миграцию как внешнеполитический ресурс. Как показывают приведённые примеры, «управление» миграционными потоками может предприниматься в целях получения преференция в торговле, принуждения к сотрудничеству в асимметричных отношениях, способа выдвинуть политическую угрозу или повысить градус конфликта. Применение концепции statecraft к анализу миграции позволяет выявить преимущества данной концепции как инструмента анализа по сравнению с традиционными исследованиями внешней политики (foreign policy analysis). Например, попытки выявить долгосрочную стратегию государств посредством традиционного анализа внешней политики чаще всего не дают убедительных операционализируемых результатов; в то же время формы и методы управления ресурсами внешней политики государства остаются стабильными на протяжении длительного времени и могут служить надежным ориентиром для наблюдателей.
\end{abstract}

Ключевье слова:

государственное управление; национальное государство; секьюритизация; миграция; Россия; США; Европейский союз. 